\title{
Reservoirs are hotspots of nitrogen cycling in peatland catchments
}

DOI:

10.1002/hyp.10892

\section{Document Version}

Accepted author manuscript

Link to publication record in Manchester Research Explorer

\section{Citation for published version (APA):}

Edokpa, D., Evans, M., \& Rothwell, J. (2016). Reservoirs are hotspots of nitrogen cycling in peatland catchments. Hydrological Processes, 30(20). https://doi.org/10.1002/hyp.10892

\section{Published in:}

Hydrological Processes

\section{Citing this paper}

Please note that where the full-text provided on Manchester Research Explorer is the Author Accepted Manuscript or Proof version this may differ from the final Published version. If citing, it is advised that you check and use the publisher's definitive version.

\section{General rights}

Copyright and moral rights for the publications made accessible in the Research Explorer are retained by the authors and/or other copyright owners and it is a condition of accessing publications that users recognise and abide by the legal requirements associated with these rights.

\section{Takedown policy}

If you believe that this document breaches copyright please refer to the University of Manchester's Takedown Procedures [http://man.ac.uk/04Y6Bo] or contact uml.scholarlycommunications@manchester.ac.uk providing relevant details, so we can investigate your claim.

\section{OPEN ACCESS}




\title{
Reservoirs are hotspots of nitrogen cycling in peatland catchments
}

\author{
D.A. Edokpa*, M.G. Evans, and J.J. Rothwell
}

Upland Environments Research Unit, School of Environment, Education and Development

The University of Manchester, Oxford Road, M13 9PL, United Kingdom

*donald.edokpa@manchester.ac.uk 


\begin{abstract}
This study presents input-output budgets of total dissolved nitrogen (TDN), dissolved organic $\mathrm{N}(\mathrm{DON})$ and dissolved inorganic $\mathrm{N}$ (DIN) for a reservoir in a peatland catchment in the south Pennines (UK). This site receives high levels of atmospheric inorganic $\mathrm{N}$ deposition, in the range of $26 \mathrm{~kg} \mathrm{~N} \mathrm{ha}^{-1} \mathrm{yr}^{-1}$. The results show that the reservoir retains $\sim 21$ to $31 \%$ of the annual TDN input $(8806 \pm 741 \mathrm{~kg} \mathrm{~N})$. Approximately 39 to $55 \%$ of DON $(3782 \pm 653 \mathrm{~kg} \mathrm{~N})$ and 6 to $13 \%$ of DIN $(5024 \pm 349 \mathrm{~kg} \mathrm{~N})$ was retained/processed. A long water retention time (104 days), average annual $\mathrm{pH}$ of 6.5 , high concentrations of DIN in the reservoir water and a deep water column suggests that denitrification is potentially a key mechanism of $\mathrm{N}$ retention/removal. The results also demonstrate that DON is potentially photodegraded and utilised within the reservoir, particularly during the summer season when 58 to $80 \%$ of DON input $(682 \pm 241 \mathrm{~kg} \mathrm{~N})$ was retained, and a net export of DIN $(\sim 34 \mathrm{~kg} \mathrm{~N})$ was observed. The findings therefore suggest that DON may play a more crucial role in the biogeochemistry of peat-dominated acid sensitive upland freshwater systems than previously thought. Reservoirs, impoundments, and large lakes in peatland catchments may be important sites in mediating downstream $\mathrm{N}$ transport and speciation.
\end{abstract}

Keywords: Nitrogen; Reservoir; Nutrient budget; Peat; DON; south Pennines 


\section{Introduction}

The use of nutrient input-output budgets as a method for evaluating the impacts of anthropogenic activities on the fluvial environment has long been recognised (Vogt et al., 2013; Rothwell et al., 2008; Cooper, 2005; Winter et al., 2002; Crisp, 1966). Freshwater acidification from high atmospheric sulphur $(\mathrm{S})$ and inorganic nitrogen $(\mathrm{N})$ deposition is a major water quality problem in many upland environments in the Northern Hemisphere (Aherne et al., 2003; Skjelkvale et al., 2003; Curtis et al., 2000; Evans et al., 2000; Stoddard et al., 1999). Although a significant decline in S deposition has been observed (Futter et al., 2014; Curtis et al., 2005; Cooper and Jenkins, 2003; Dillon et al., 2003), N deposition has remained high in some upland regions (Helliwell et al., 2007; Evans et al., 2000; Goodale et al., 2000; Aber et al., 2003). Elevated N deposition alters biogeochemical cycling in lakes and freshwater systems (Elser et al., 2009, 2007; Wolfe et al., 2001), potentially resulting in deleterious ecological consequences (Lepori and Keck, 2012; Baron et al., 2011). In areas of high $\mathrm{N}$ input, reservoirs or lakes with their large surface area for nutrient exchange and turnover (Durand et al., 2011; Shotbolt et al., 2005; Thornton et al., 1990) can be effective traps of $\mathrm{N}$, thus mediating the downstream effects of excess $\mathrm{N}$ loading (Jansson et al., 1994).

Reservoirs contain a significant array of biological assemblages that directly utilise dissolved nutrients (Kelly, 2001), with the stream-reservoir-stream fluvial system offering a unique environment for understanding the changes of dissolved $\mathrm{N}$ at a range of temporal scales. The interaction between the chemistry of inflowing water and the processes occurring within reservoirs influences the downstream transport of nutrients (Thornton et al., 1990), and gives extra significance to reservoir outlets (Toetz, 1973). Reservoirs play important roles in the global carbon (C) cycle; acting as recipients of dissolved organic, inorganic, and particulate organic C (DOC, DIC and POC, respectively), as well as producers of greenhouse gases, 
including carbon dioxide $\left(\mathrm{CO}_{2}\right)$, methane $\left(\mathrm{CH}_{4}\right)$ and nitrous oxide $\left(\mathrm{N}_{2} \mathrm{O}\right)$ (Battin et al., 2009; Tranvik et al., 2009). Large amounts of $\mathrm{C}$ and $\mathrm{N}$ are stored by reservoirs and lakes through sedimentation (Kunz et al., 2011; Tranvik et al., 2009; David et al., 2006; Jansson et al., 1994). The global annual burial rate of organic C (OC) by sediments of reservoirs is estimated to be $160 \mathrm{Tg} \mathrm{yr}^{-1}$; 3.8 times higher than in lake sediments (Dean and Gorham, 1998). Although the growing demand for water due to the increasing needs of a rising human population may increase the propagation of impoundments across the globe (Downing et al., 2006), alongside the associated impacts of such landscape modifications (Tranvik et al., 2009), recent studies have suggested that the number of large dam construction projects has levelled off in the last 10-15 years (Steffen et al., 2015).

The extensive Pennine uplands of the UK contain a remarkable number of reservoirs that provide a vital source of drinking water to the surrounding urban population (Evans et al., 2000; Shotbolt et al., 2000). A significant proportion of this peatland environment is heavily eroded and extensively gullied (Tallis, 1997), with organic sediment yields of $\sim 200 \mathrm{t} \mathrm{km}^{-2} \mathrm{a}^{-1}$ (Evans et al., 2006). As a consequence, water supply reservoir catchments in these uplands are generally managed (stabilisation of soils, moorland restoration and protection of watercourses) to ensure the provision of good water quality (United Utilities, 2011), with major focus on DOC removal; the most significant cost to water treatment in the UK (Worrall et al., 2004). Whilst soil erosion and sediment transport of particulate nutrients to reservoirs and impoundments constitute redistribution or translocation of nutrient sinks within catchments (Battin et al., 2009; Downing et al., 2008; Ittekkot and Zhang, 1989), the focus of our study was on the biologically active component of $\mathrm{N}$ - dissolved $\mathrm{N}$; one of the most common chemical metrics used to evaluate freshwater ecosystem health (Roley et al., 2014). At present, there is a significant deficiency in current understanding of the role of reservoirs 
as mechanisms of $\mathrm{N}$ retention, cycling and removal in peat-dominated catchments where high atmospheric $\mathrm{N}$ deposition coincides with a high density of reservoir impoundments supplying major urban areas, for example in northern England. The main objective of this study was to produce a total dissolved $\mathrm{N}(\mathrm{TDN})$, dissolved inorganic $\mathrm{N}$ (DIN) and dissolved organic $\mathrm{N}$ (DON) budget for a reservoir in an acid-sensitive peatland catchment in the south Pennines. Consideration of DON budgets in this context is novel and central to providing insight into biogeochemical cycling of $\mathrm{N}$ in a peatland context. This data will quantify the role of the reservoir as a sink or source of $\mathrm{N}$. This will provide a better understanding of $\mathrm{N}$ dynamics in one of the most acidified upland regions of the UK, and will assist in constraining estimates of $\mathrm{N}$ fluxes downstream of stream-reservoir systems.

\section{Study site}

This study was conducted in the Kinder Reservoir catchment in the Dark Peak, south Pennines, UK (Figure 1). Rainfall for the catchment is $\sim 1157 \mathrm{~mm}$, whilst average air temperature is $8.5^{\circ} \mathrm{C}$ (Dec 2012 - Nov 2013 data). The Kinder Reservoir is fed by three main sub-catchments or inlets: William Clough (WC), Kinder River (KR) and Broad Clough (BC). Water is abstracted from the reservoir at an engineered channel with a known stage-discharge relationship in the bottom valve house $(\mathrm{VH})$, whilst the specific volume of water or extra draw-off are occasionally released to the stream to fulfil legal obligations. This released water plus any overflow (spillway) over the dam (which mainly occurs in the winter months) represents the reservoir overflow (KRO). A combination of $\mathrm{VH}$ and $\mathrm{KRO}$ constitute the reservoir outlet. The morphometric details of the Kinder Reservoir and its main tributaries are given in Table 1.

Table 1: Morphometry of Kinder Reservoir and its main tributaries 
Kinder Scout, overlain by blanket peat deposits of 2-4 m thick, marks the highest point (633 m) of the catchment. The geology of the catchment is dominated by grit and coarse sandstones. Approximately $2.6 \mathrm{~km}^{2}$ of the catchment is blanket peat, with very acid loamy soils occurring mostly in the $\mathrm{WC}$ and $\mathrm{BC}$ sub-catchments. The vegetation cover of the catchment is mainly blanket bog, acid grassland, heather and shrub heathland, with small plots of improved grassland. Dense patches of bracken are also present on the hillsides, with sparse alder and birch tree cover scattered across the lower catchment valleys. There is lowintensity sheep grazing within the catchment. To ensure high water quality provision, the catchment is generally managed to limit organic, particulate and nutrient losses from the terrestrial environment to the watercourses (United Utilities, 2011). A small part of the KR headwater has undergone some form of peatland restoration (Edokpa et al., 2015).

Figure 1: Study site location

\section{Materials and Methods}

\subsection{Water sampling and analyses}

High resolution stormflow monitoring (15 min to $1 \mathrm{~h}$ interval) and fortnightly samples were collected between December 2012 and November 2013 from the reservoir inlets (WC, KR and BC). Fortnightly sampling was also conducted at VH and KRO. A total of 240 high resolution and 75 fortnightly samples were collected at the reservoir inlets. A combined total of 49 fortnightly samples were collected at the VH and KRO. Twenty-five (25) fortnightly water samples were also collected at the west side of the reservoir (R), where mixing of waters from the three inlets was assumed to be readily captured. Details of sample collection are shown in Table 2. Samples were syringe filtered through $0.45 \mu \mathrm{m}$ Whatman $\mathrm{G} / \mathrm{F}$ 
membrane filter into sterile plastic vials. All samples for chemical analysis were stored at 4 ${ }^{\circ} \mathrm{C}$ prior to analysis, except samples for ammonium $\left(\mathrm{NH}_{4}{ }^{+}\right)$determination, which were frozen to significantly reduce biological degradation (Cape et al., 2001). Laboratory analysis was carried out within a few days of sample collection. TDN was analysed using a Shimadzu TOC-V CPN ASI-V analyzer with a TNM-1 unit. DON was determined as TDN minus DIN; where DIN is the sum of $\mathrm{NO}_{3}{ }^{-}, \mathrm{NO}_{2}{ }^{-}$and $\mathrm{NH}_{4}{ }^{+}$. Nitrate $\left(\mathrm{NO}_{3}{ }^{-}\right)$nitrite $\left(\mathrm{NO}_{2}{ }^{-}\right)$and $\mathrm{NH}_{4}{ }^{+}$were analysed using a Metrohm 882 COMPACT IC PLUS ion chromatograph.

Table 2: Sampling details

\subsection{Rainfall data and stream hydrological monitoring}

Rainfall for the catchment was obtained from a rain gauge station established at close proximity to the Kinder Reservoir outlet and assumed to be representative of the entire catchment. Rainwater chemistry samples were collected at the reservoir inlets using polythene filter funnels which drained into Nalgene bottles pre-rinsed with deionised water. Daily discharge at the reservoir outlet was recorded at a calibrated engineered channel with a known stage-discharge relationship. The reservoir inlets were ungauged, thus stage-discharge relationships for the individual sites were established from a series of flow measurements using an electromagnetic flow meter (SENSA RC2) under a range of flow conditions. Stage and air temperature were continuously recorded at $15 \mathrm{~min}$ interval on the rated sections of the reservoir inlets using TruTrack WT-HR 64K capacitance probes with internal data logger. The probes were embedded in hard plastic PVC tubes and attached to river banks. Calibrated measuring boards were attached to the PVC tubes and manually read off at the time of sampling. This provided an independent check on the performance of the logger(s) and was 
used to correct for logger drift. Recorded stage values for the inlets were inputted into the respective rating curves and used to calculate discharge.

\subsection{Water balance calculation}

For this type of study, it is important to derive an input-output water-balanced budget, before calculating the input-output fluxes of nutrients (Crisp, 1966) to reduce the uncertainty or error in flux estimation (Adams et al., 2013). This makes water balance closure a crucial component in catchment-scale hydrological processes (Beven, 2006). We adopted a simple inout water balance model which was based on inlet and outlet discharge data, including direct rainfall and evaporation. The main assumption in our water balance calculation was that the uncertainty associated with the discharge data recorded at the calibrated engineered channel at the reservoir outlet was negligible, and could therefore be ignored. Groundwater exchanges were also considered and assumed to be negligible on the basis of the distribution in the positive residuals of the water balance, and consultation with the reservoir manager. Therefore, it was assumed that error in the water balance was associated with measurement of inlet discharges. To create a closed water balance, the inlet discharges derived from the rating curves were corrected with data from the reservoir outlet. The difference between the sum of all inlet and outlet discharges (after accounting for evaporation and reservoir drawdown) was added to (or subtracted from, depending on reservoir filling/emptying) the sum of outlet discharge to obtain the target inlet discharge $\left(T_{\text {in }}\right)$. The discharge from the individual inlet site was then ratio-corrected to arrive at a balanced in-out water budget using the following equation:

$$
R C Q=I_{\mathrm{s}} Q / T_{\mathrm{i}} Q * T_{\mathrm{in}}
$$

Where, $R C Q=$ ratio corrected discharge, $I_{\mathrm{s}} Q=$ individual inlet site discharge, $T_{\mathrm{i}} Q=$ total inlet discharge, and $T_{\text {in }}=$ target inlet discharge. 
The recorded 15 min discharge data from the logger(s) were then multiplied by the percentage change between the sum of the uncorrected inlet discharge and the ratio-corrected discharge, from which fluvial $\mathrm{N}$ fluxes were derived. The uncorrected and corrected discharge hydrographs for the inlet sites are shown in Figure 2. Reservoir drawdown data was provided by United Utilities, and evaporation was calculated using the simplified Penman evaporation formula (Linacre, 1977), given as:

$\mathrm{E}_{0}=\frac{700 T_{\mathrm{m}} /(100-A)+15\left(T-T_{\mathrm{d}}\right)\left(\mathrm{mm} \mathrm{day}^{-1}\right)}{(80-T)}$

Where;

$T_{\mathrm{m}}=T+0.006 h$,

$h=$ elevation (metres)

$T=$ mean temperature

$A=$ latitude (degrees)

$T_{\mathrm{d}}=$ mean dew-point

$\left(T-T_{\mathrm{d}}\right)=0.0023 h+0.37 T+0.53 R+0.35 R_{\mathrm{ann}}-10.9^{\circ} \mathrm{C}$ (provided precipitation is at least 5

mm a month and $T-T_{\mathrm{d}}$ is at least $4^{\circ} \mathrm{C}$ ), where $R=$ mean daily range of temperature and $R_{\mathrm{ann}}$ is the difference between the mean temperature of the hottest and coldest month.

Figure 2: Corrected and uncorrected discharge (Q) hydrographs for (a) William Clough (WC), (b) Kinder River (KR), and (c) Broad Clough (BC) Kinder Reservoir inlet sites.

\subsection{Fluvial nitrogen load estimation}

To obtain fluvial N (DON, DIN) input from the inlets and output from the reservoir, measured concentrations were multiplied by discharge. The fluxes from the individual inlets $(\mathrm{WC}+\mathrm{KR}+\mathrm{BC})$ were summed and represent the total fluvial $\mathrm{N}$ input to the reservoir, whilst fluxes from $\mathrm{VH}$ and $\mathrm{KRO}$ were summed to give reservoir $\mathrm{N}$ output. The regression 
(extrapolation) method (Haggard et al., 2003) was used to estimate input fluxes of $\mathrm{N}$ when good relationships were found between discharge and concentration (Table 3).

Table 3: Linear regression models and flux estimation method for the Kinder Reservoir inlets Rating curves were created using log-transformed concentration and discharge data from both fortnightly and high resolution sampling. The Duan (1983) smearing estimator was used to correct for back transformation error whilst, the standard error of the regression line was used to calculate the error in the estimated flux. In cases where there was a poor relationship $\left(\mathrm{R}^{2}<\right.$ 0.20 and $p>0.05$ ) between discharge and concentration, the Walling and Webb (1985) 'Method 5' (interpolation) approach was used to estimate $\mathrm{N}$ fluxes using only fortnightly concentration data (Table 3). Annual and seasonal reservoir output fluxes of $\mathrm{N}$ were also estimated using Walling and Webb (1985) 'Method 5', as discharge was relatively constant at the reservoir outlet. The Walling and Webb (1985) 'Method 5' takes the following form:

Total Load $=\frac{K \sum_{i=1}^{n}\left(c_{i} Q_{i}\right)}{\sum_{i=1}^{n} Q_{i}} \overline{Q_{r}}$

Where;

$\mathrm{K}=\mathrm{a}$ conversion factor to take into account the period of monitoring

$\mathrm{C}_{i}=$ the concentration associated with each sample point

$\mathrm{Q}_{i}=$ the discharge at time of sampling

$\overline{\mathrm{Q}_{\mathrm{r}}}=$ mean discharge over the monitoring period

$n=$ the number of samples 


\subsection{Nitrogen deposition}

Total (wet + dry) atmospheric inorganic $\mathrm{N}$ deposition values modelled by the Centre for Ecology and Hydrology (CEH) using the FRAME (Fine Resolution Atmospheric Multipollutant Exchange) model were downloaded from the Defra website (http://pollutantdeposition.defra.gov.uk/data) and available on a $5 \mathrm{~km}$ grid square resolution. Average modelled value (2010-2012) was derived for the catchment by digitally overlaying the catchment area on the $5 \mathrm{~km}$ grid square resolution deposition data covering the catchment in ESRI ArcGIS. Deposition data were available for total $\mathrm{N}$, oxidised $\left(\mathrm{NO}_{\mathrm{x}}\right)$ and reduced $\left(\mathrm{NH}_{\mathrm{x}}\right) \mathrm{N}$, but not for organic $\mathrm{N}$. Wet atmospheric $\mathrm{N}$ deposition was derived for the reservoir by multiplying measured average rainwater $\mathrm{N}$ concentration by rainfall over the reservoir surface area.

\subsection{Nitrogen budget}

Annual and seasonal input-output budgets were calculated for TDN, DIN and DON (TDN minus DIN). Net gain or loss by the reservoir was derived by subtracting $\mathrm{N}$ input from reservoir output. A negative $\mathrm{N}$ balance indicates that the reservoir is acting as a sink of $\mathrm{N}$, whilst positive $\mathrm{N}$ balance is an indication that the reservoir is acting as a source of $\mathrm{N}$.

\section{4. $\quad$ Results}

\subsection{Nitrogen concentration}

Average monthly dissolved $\mathrm{N}$ concentrations for the sites are shown in Figure 3. Of all the three inlets, WC had the lowest concentration of dissolved $\mathrm{N}$, averaging $27-51 \mu \mathrm{mol} \mathrm{l}^{-1}$ in all months, except January and April, when average TDN concentrations were $\sim 66 \mu$ mol $1^{-1}$ (Figure 3a). In the KR and BC inlets, average concentrations of TDN were $\sim 80-110 \mu \mathrm{mol}^{-1}$ in January through April, but declined to $\sim 40-60 \mu \mathrm{mol} \mathrm{1}^{-1}$ for the rest of the study (Figure 3a). Average TDN concentrations at the $\mathrm{VH}$ and $\mathrm{KRO}$ were $\sim 67-99 \mu \mathrm{mol}^{-1}$ in January 
through May, but declined to $<60 \mu \mathrm{mol}^{-1}$ in the subsequent months of the study year (Figure 3a). In mid-winter (January), average concentrations of DIN reached $70 \mu \mathrm{mol} \mathrm{l}^{-1}$ in $\mathrm{KR}$, and $77 \mu \mathrm{mol} \mathrm{l}^{-1}$ in BC (Figure 3b). During the study year, average concentrations of DON in the reservoir inlets reached a peak of $\sim 67 \mu \mathrm{mol} \mathrm{l}^{-1}$ in $\mathrm{KR}$ in early summer, but were as low as $\sim$ $1-8 \mu \mathrm{mol} 1^{-1}$ in the reservoir outlet (Figure $3 \mathrm{c}$ ).

Figure 3: Average monthly concentration of (a) TDN (b) DIN and (c) DON for the Kinder Reservoir inlet (WC, $\mathrm{KR}$ and $\mathrm{BC}$ ) and outlet (VH and $\mathrm{KRO})$ sites.

The combined monthly average concentrations of dissolved $\mathrm{N}$ in the reservoir inlet and outlet, and the reservoir water residence time (WRT) are shown in Figure 4. The WRT for the study year was $\sim 104$ days (Table 1), but varied from 52 days in December, to 108 days in May (Figure 4). Average monthly concentrations of TDN in the reservoir inlet and outlet were approximately equal in December through February when WRT was $\leq 80$ days (Figure 4a). In comparison to the reservoir inlet, average concentrations of TDN declined in the outlet between March and June, coinciding with the months when the WRT was $>100$ days (Figure 4a). Variation in average concentrations of DIN between the reservoir inlet and outlet was low during the study period, except in January and November when DIN concentrations in the outlet were higher than inlet DIN concentrations (Figure 4b). In January, and March through June, average concentrations of DON were lower in the reservoir outlet in comparison to the inlet (Figure 4c). Average concentrations of DIN in the reservoir were $\sim 26-45 \mu \mathrm{mol} \mathrm{l}^{-1}$ during the study year, except in January when it reached $55 \pm 4 \mu \mathrm{mol} \mathrm{l}^{-1}$ (Figure 4d). Monthly average concentrations of DON in the reservoir varied widely, reaching $53 \pm 1 \mu \mathrm{mol}^{-1}$ in April and declining to $16 \mu \mathrm{mol} \mathrm{l}^{-1}$ in May (Figure 4d). 
Figure 4: Monthly average inlet and outlet concentrations of (a) TDN (b) DIN (c) DON, and (d) DIN and DON concentrations in the Kinder Reservoir. Error bars represent the standard error of the mean. Water residence time (estimated as reservoir volume divided by total discharge from its outlet) is plotted on the TDN, DIN and DON graphs.

There were no marked changes between average annual and seasonal concentrations of TDN in the reservoir inlet and outlet, except in summer (Figure 5a) when there was a $45 \pm 2 \%$ decrease in concentration of TDN in the outlet in comparison with inputs (Figure 6a). The summer decrease in outlet TDN was linked to the decrease in summer DON (Figure 4c). The highest percentage decrease $(78 \pm 2 \%)$ in DON concentration in the reservoir outlet relative to its inlet was observed in early summer (June) when WRT was $\sim 105$ days (Figure 6a and b). Average annual DIN and DON concentration for the combined reservoir inlets was $37 \mu \mathrm{mol} 1^{-}$ ${ }^{1}$ and $31 \mu \mathrm{mol} \mathrm{l}^{-1}$, respectively (Figure $5 \mathrm{~b}$ and c). Relative to inputs from inlet streams, there was a $13 \pm 2 \%$ decrease in DIN concentration in the reservoir outlet in summer (Figure 6a). Average seasonal concentrations of DIN in the Kinder Reservoir were higher in the winter $\left(45 \pm 5 \mu \mathrm{mol} \mathrm{l}^{-1}\right)$ and spring $\left(44 \pm 1 \mu \mathrm{mol} \mathrm{l}^{-1}\right)$ seasons, compared to the summer and autumn seasons (Figure 5b).

Figure 5: Average annual and seasonal concentrations of (a) TDN (b) DIN, and (c) DON for the three inlets, Kinder Reservoir and its outlet. Error bars represent the standard error of the mean. 
Figure 6: Change (as a percentage of fluvial input concentration) in average (a) annual, seasonal, and (b) monthly dissolved $\mathrm{N}$ concentration between fluvial input of $\mathrm{N}$ from the combined inlets and outlet. Error bars represent \% standard error of the mean.

\subsection{Water balance}

Rainfall and stream discharge from the reservoir inlets and outlet for the study year are shown in Table 4. Stream discharge to the reservoir was 8.11 million $\mathrm{m}^{3}$, whilst direct rainfall over the reservoir free surface was 0.21 million $\mathrm{m}^{3}$. Total water input (stream flow plus direct rainfall over the reservoir surface) to the reservoir was 8.32 million $\mathrm{m}^{3}$ and water output from the reservoir was 8.25 million $\mathrm{m}^{3}$, with reservoir evaporation accounting for the $\sim 1 \%$ imbalance $\left(0.07\right.$ million $\left.\mathrm{m}^{3}\right)$ in the water budget. Drawdown for the study period equates to zero, but varied monthly depending on the volume of water in the reservoir. A negative drawdown indicates that the reservoir is emptying whilst a positive drawdown value indicates reservoir filling.

Table 4: Water balance for Kinder reservoir (Dec 2012- Nov 2013). Note: units are million $\mathrm{m}^{3}$

To demonstrate that the input fluxes and $\mathrm{N}$ balance results derived using the ratio-corrected (water-balanced) discharge are significant, we examined the sensitivity of the fluvial input of $\mathrm{N}$ by separately deducting the sum of the error (excess water) in the inlet discharge from each of the inflow (KR, BC and $\mathrm{WC})$ measurement. This produced three different flux and $\mathrm{N}$ balance scenarios, in addition to $\mathrm{N}$ fluxes derived using ratio-corrected discharge. For simplicity, fluxes were calculated by multiplying average annual TDN concentration by total annual discharge. In the first scenario (when the total error in the inlet discharge was deducted from only the KR inflow measurement), total fluvial input of $\mathrm{N}$ to the reservoir was $7491 \mathrm{~kg}$ 
$\mathrm{N}$, with a retention of $14 \%(1062 \mathrm{~kg} \mathrm{~N})$. In the second scenario (when the total error in the inlet discharge was deducted from only the $\mathrm{BC}$ inflow measurement), total fluvial input of $\mathrm{N}$ to the reservoir was $8059 \mathrm{~kg} \mathrm{~N}$, with a retention of $20 \%(1630 \mathrm{~kg} \mathrm{~N})$. For the third scenario (when the total error in the inlet discharge was deducted from only the WC inflow measurement), total fluvial input of $\mathrm{N}$ to the reservoir was $8470 \mathrm{~kg} \mathrm{~N}$, with a retention of $24 \%$ (2041 kg N). The fluvial input of $\mathrm{N}$ to the reservoir calculated using the ratio-corrected discharge produced a flux of $7893 \mathrm{~kg} \mathrm{~N}$, with a retention of $19 \%(1464 \mathrm{~kg} \mathrm{~N})$; about the average percentage retention of the other three scenarios. These results suggest that variability resulting from the spatial lumping of discharge correction to any of the separate inflows does not substantially alter the conclusions of the $\mathrm{N}$ mass balance calculated using the ratiocorrected inlet discharge method.

\subsection{Fluxes of nitrogen}

The Kinder Reservoir catchment received $25.6 \mathrm{~kg} \mathrm{~N}^{-1} \mathrm{yr}^{-1}$ of atmospheric inorganic $\mathrm{N}$ deposition (2010-2012 CEH modelled average). Measured wet atmospheric $\mathrm{N}$ input to the free reservoir surface area was $7.44 \pm 1.05 \mathrm{~kg} \mathrm{~N} \mathrm{ha}^{-1} \mathrm{yr}^{-1}$. There was marked winter-summer variation in the fluxes of TDN, DIN and DON to the Kinder Reservoir from its subcatchments (WC, KR and $\mathrm{BC}$ ), with winter high and summer low (Table 5) reflecting the pattern of discharge (Table 4) and biological demand. Relative to DON, fluxes of DIN made up a higher proportion of the TDN flux to the reservoir in all seasons except in the very peaty KR sub-catchment where DON was dominant in all but the spring season (Table 5). Annual flux of TDN from the Kinder Reservoir catchment was $7.45 \pm 0.11 \mathrm{~kg} \mathrm{~N}^{-1} \mathrm{yr}^{-1}$, with DIN making up $\sim 70 \%$ of the flux (Table 5). Fluxes of TDN from the reservoir catchment were highest in winter $\left(3.08 \pm 0.09 \mathrm{~kg} \mathrm{~N}^{-1}\right.$ season$)$ and lowest in summer $\left(1.07 \pm 0.003 \mathrm{~kg} \mathrm{~N} \mathrm{ha}^{-1}\right.$ 
season). DON constituted $\sim 20 \%$ of the TDN flux from the reservoir catchment in summer, and between $30-33 \%$ in the other seasons (Table 5).

Table 5: Seasonal and annual fluxes per unit area $\left(\mathrm{kg} \mathrm{N} \mathrm{ha}^{-1}\right)$ calculated using the surface areas shown in Table 1.

\subsection{Kinder Reservoir nitrogen mass balance}

The N mass balance we constructed for the Kinder Reservoir for December 2012 through November 2013 is shown in Figure 7 and Table 6. Riverine $\mathrm{N}$ input to the reservoir was dominated by DIN $(4946 \pm 349 \mathrm{~kg} \mathrm{~N})$, and represented $57 \pm 4 \%$ of the annual fluvial $\mathrm{N}$ input (Table 6). Fluvial input of DON to the reservoir ranged between 3074 and $4380 \mathrm{~kg} \mathrm{~N}$ (Table 6). Measured wet atmospheric deposition $(133 \pm 19 \mathrm{~kg} \mathrm{~N})$ was a minor contributor to total $\mathrm{N}$ input (Figure 7). The net loss of dissolved $\mathrm{N}$ to the Kinder Reservoir during the study year was $2309 \pm 747 \mathrm{~kg} \mathrm{~N}$. Approximately $90 \pm 3 \%(4539 \pm 132 \mathrm{~kg} \mathrm{~N})$ of annual DIN input was exported from the reservoir, implying a percentage retention of $10 \pm 3 \%$ (Figure 7 ).

Table 6: Seasonal and annual mass balance of fluvial N ( $\mathrm{kg} \mathrm{N}$ ) for Kinder Reservoir (Dec 2012-Nov 2013). Percentage retention was calculated as the difference between output minus input of $\mathrm{N}$ as a percentage of input. A negative $\mathrm{N}$ balance indicates that the reservoir is acting as a sink of $\mathrm{N}$, whilst positive $\mathrm{N}$ balance is an indication that the reservoir is acting as a source of $\mathrm{N}$.

The retention of DON as a percentage of $\mathrm{N}$ inputs to the reservoir ranged between $39-55 \%$ (1216 - $2432 \mathrm{~kg} \mathrm{~N}$ ) during the study (Figure 7). The status of the reservoir as a sink or source of $\mathrm{N}$ species varied between seasons (Table 6). In spring, the Kinder Reservoir was a source 
of DIN (225 - $248 \mathrm{~kg} \mathrm{~N})$, and a sink or source of DON when considered within the margin of error (Table 6). In the vegetative season (summer), 58 to $\sim 80 \%(225-730 \mathrm{~kg} \mathrm{~N})$ of DON was retained by the reservoir, whilst there was between a $1 \%(5 \mathrm{~kg} \mathrm{~N})$ retention or an $11 \%(74$ $\mathrm{kg} \mathrm{N}$ ) net increase in DIN export from the Kinder Reservoir (Table 6).

Figure 7: Schematic of dissolved N mass balance for the Kinder Reservoir (December 2012 to November 2013). Fluxes are proportional to thickness of the arrows in the diagram.

\section{Discussion}

Consistent with other mass-balance studies (e.g. David et al., 2006; Kelly, 2001; Garnier et al., 1999), this study demonstrates the capacity of reservoirs to remove/retain more than $30 \%$ of $\mathrm{N}$ inputs. Most of these studies have been focused on DIN, thus limiting our understanding of DON cycling in stream-reservoir systems. Garnier et al. (1999) estimated a 40\% retention of $\mathrm{NO}_{3}{ }^{-}$inputs in three reservoirs of the Seine Basin, whilst $29 \%$ of $\mathrm{NO}_{3}{ }^{-}$input (March 2002 through March 2013) to Lake Shelbyville reservoir was retained/removed (David et al., 2006). Our mass balance for the Kinder Reservoir shows an annual net retention of $\sim 26 \%$ for TDN, $\sim 10 \%$ for DIN and $\sim 48 \%$ for DON (Figure 7 ). The low retention of DIN is not surprising, considering that the catchment has been exposed to decades of atmospheric inorganic $\mathrm{N}$ deposition (Edokpa et al., 2015; Helliwell et al., 2007). At the whole catchment scale, atmospheric inorganic $\mathrm{N}$ deposition was $25.6 \mathrm{~kg} \mathrm{~N} \mathrm{ha}^{-1} \mathrm{yr}^{-1}$, whilst the flux of DIN from the Kinder Reservoir catchment was $5.21 \pm 0.15 \mathrm{~kg} \mathrm{~N} \mathrm{ha}^{-1} \mathrm{yr}^{-1}$ (Table 5), suggesting that $\sim 20 \%$ of DIN input was leached from the catchment. At the sub-catchment scale, $11.1 \pm 1.08 \mathrm{~kg} \mathrm{~N} \mathrm{ha}^{-1}$ $\mathrm{yr}^{-1}$ of DIN was leached from BC; $5.26 \pm 0.69 \mathrm{~kg} \mathrm{~N} \mathrm{ha}^{-1} \mathrm{yr}^{-1}$ from KR, and $3.49 \pm 0.17 \mathrm{~kg} \mathrm{~N} \mathrm{ha}^{-1}$ $\mathrm{yr}^{-1}$ from WC (Table 5) during the study. This is reminiscent of catchments at advanced stage of $\mathrm{N}$ leaching, characterised by accelerated nitrification and reduced biological demand (Aber 
et al., 1995; Stoddard, 1994). In addition to atmospheric inorganic N deposition, the rapid mineralisation of organic $\mathrm{N}$ stored in the peat soils of the catchment may also encourage DIN leaching to the surface waters (Daniels et al., 2012).

The Kinder Reservoir switched from being a sink of TDN in the biologically dormant winter season, to being a source of $\mathrm{N}$ in the spring season, with $\sim 237 \mathrm{~kg} \mathrm{~N}$ of DIN exported in excess of fluvial DIN input (Table 6). Although immobilisation of DIN was slightly higher than mineralisation in winter, in spring, mineralisation is as much or greater than immobilisation, thus allowing for the direct export of DIN from the catchment (Lin et al., 2015). Whilst a $42 \pm 5 \%$ decrease in the annual average DON concentration was observed in the reservoir outlet, relative to fluvial inputs (Figure 6), there was little or no difference between the average annual concentrations of DIN in the Kinder Reservoir, and its inlet and outlet (Figure 5b). This may suggest the mineralisation of DON into DIN in the reservoir, or the direct utilisation of atmospherically deposited inorganic $\mathrm{N}$ by the biological assemblage of the reservoir, such that, there is an accumulation of DIN derived from other sources e.g. mineralisation. Yesmin et al (1995) suggest that the high retention of $\mathrm{NO}_{3}{ }^{-}$and $\mathrm{NH}_{4}{ }^{+}$at their most polluted sites may be due to the preponderance of direct biomass utilisation of inorganic $\mathrm{N}$ in precipitation, as opposed to DIN derived from mineralisation/nitrification. However, recent isotope studies suggest that most $\mathrm{NO}_{3}{ }^{-}$in upland waters have been biologically produced (Curtis et al., 2012).

Interestingly, in the vegetative season (summer), DIN export from the Kinder Reservoir was greater than or approximately equal to its input, whilst 58 to $\sim 80 \%$ of DON was retained by the reservoir (Table 6). Two candidate mechanisms are potentially responsible for the large amount of DON retained by the reservoir in summer. The first mechanism involves the preferential sorption of total hydrolysable and N-rich amino acids to fine-grained minerogenic 
particles (Hedges and Keil, 1999; 1995) in the reservoir. The second mechanism involves mineralisation via photochemical degradation of DON/dissolved organic matter (DOM) (Vahatalo and Zepp, 2005; Kohler et al., 2002; Bertilsson and Tranvik, 2000) and/or the rapid consumption of the resultant bioavailable low molecular weight (LMW) DON photoproducts (e.g. dissolved primary amines) by the microbial assemblage (Jorgensen et al., 1998; Fuhrman, 1990) of the reservoir. Based on the seasonal behaviour of DON in this study (Figure 4, 5 and 6), and findings from elsewhere (Kaushal and Lewis, 2005; Kohler et al., 2002; Bertilsson and Tranvik, 2000; Jorgensen et al., 1998; Seitzinger and Sanders, 1997), we suggest the latter mechanism as the most likely explanation for the marked reservoir retention of DON in summer (Table 6). Solar radiation can transform photoreactive but biologically recalcitrant DON/DOM into $\mathrm{NH}_{4}^{+}$(Vahatalo and Zepp, 2005; Moran and Zepp, 1997), thereby decreasing DON, and increasing the DIN pool in the reservoir. This may help explain the high export of DIN from the Kinder Reservoir relative to input in summer (Table 6). Whilst some retention/export of dissolved $\mathrm{N}$ may be due to precipitation of particulate $\mathrm{N}$, the overall seasonal dynamics of fluvial $\mathrm{N}$ strongly suggest that biological processes (possibly complemented by abiotic processes) is the dominant control of $\mathrm{N}$ in this peatland system.

The other mechanisms of $\mathrm{N}$ retention/removal in freshwater systems include uptake of $\mathrm{N}$ by aquatic plants, denitrification and sedimentation (David et al., 2006; Saunders and Kalff, 2001; Noges et al., 1998). As a primary mechanism of $\mathrm{N}$ retention, uptake of $\mathrm{N}$ by aquatic plants is often viewed as a temporary sink of $\mathrm{N}$, and the least effective mechanism of $\mathrm{N}$ retention in freshwaters (Saunders and Kalff, 2001; Jansson et al., 1994), due to remineralisation into the water column when the plants die (Ensign and Doyle, 2006; Jansson et al., 1994). 
Denitrification, as an important pathway of $\mathrm{N}$ removal in aquatic systems (Saunders and Kalff, 2001; Jansson et al., 1994), has both geochemical and ecological significance, including the control of eutrophication in freshwaters receiving high $\mathrm{N}$ deposition (Seitzinger, 1988). Similar to denitrification is the process of dissimilatory nitrate reduction to ammonia (DNRA), wherein heterotrophic bacteria utilise $\mathrm{NO}_{3}^{-}$as a terminal electron acceptor in respiration to reduce $\mathrm{NO}_{3}{ }^{-}$to gaseous $\mathrm{N}$ compounds $\left(\mathrm{NO}, \mathrm{N}_{2} \mathrm{O}\right.$ and $\mathrm{N}_{2}$ ) or $\mathrm{NH}_{4}{ }^{+}$(Rutting et al., 2011; Katterer et al., 2011; Scott et al., 2008). Although denitrification and DNRA occur under low oxygen condition, $\mathrm{C} / \mathrm{NO}_{3}{ }^{-}$has been identified as a key factor regulating the partitioning of both processes (Fazzolari et al., 1998; Yin et al., 1998). The Kinder Reservoir catchment is exposed to high atmospheric $\mathrm{NO}_{3}{ }^{-}$deposition, and average $\mathrm{C} / \mathrm{NO}_{3}{ }^{-}$for the reservoir during the study year was $<5\left({\mathrm{C} / \mathrm{NO}_{3}}^{-}\right.$data not presented here). Also, some parts of the reservoir reach depths of $>11 \mathrm{~m}$, and depending on mixing, anoxia occurs at lake depths of $\geq 9 \mathrm{~m}$ (Chapman et al., 1998). Although denitrification rate was not directly measured in this study, the observed low $\mathrm{C} / \mathrm{NO}_{3}^{-}(<5)$ inhibits DNRA, but increases denitrification under anoxic conditions (Fazzolari et al., 1998); thus making denitrification a potential pathway of $\mathrm{N}$ loss from the Kinder Reservoir water column. Whilst oxygen is the main regulator of denitrification, $\mathrm{pH}$ has been identified as a major controlling factor of denitrification rates (Sun et al., 2012). Average $\mathrm{pH}$ for water in the Kinder Reservoir was $\sim 6.5$ during the study year, and was as high as 7.1 in the summer month of June (Figure 8) when the most marked decrease in fluvial TDN output, relative to input was observed (Figure 6b). Although most studies have shown that denitrification is positively related to $\mathrm{pH}$, with an optimum range of 7 - 8 (Wang et al., 1995; Weier and Gilliam, 1986; Knowles, 1982), there is evidence to suggest that denitrifying activity is significant at a $\mathrm{pH}$ range of $6-7$ (Bradley et al., 1992; Klemedtsson et al., 1977). The C-rich (peat) soils of the reservoir catchment ensures that denitrifiers have access to a large supply of OC, which serves as an energy source and 
electron donor in the denitrification process (Brodrick et al., 1988; Knowles, 1982). In addition, average concentrations of DIN in the reservoir were fairly high in spring through early summer (Figure $4 d$ and $3 b$ ) when denitrification rates were found to be highest (e.g. David et al., 2006).

Figure 8: Monthly average $\mathrm{pH}$ of Kinder Reservoir water (December 2012 to November 2013)

Sedimentation of dead plankton or organic material may be another pathway of $\mathrm{N}$ loss/retention in the Kinder Reservoir. Sorption to settling and sedimenting particles in reservoirs/lakes (Kunz et al., 2011; David et al., 2006; Tang and Xie, 2000) is influenced by the DIN concentration of overlying water (Gruca-Rokosz et al., 2009), the sediment composition and associated structure of organic compounds (Henrichs and Sugai, 1993), and the population of pelagic and benthic organisms (Durand et al., 2011). Active erosion of peat soils which may transport organic particles as suspended sediments to the reservoir has previously been reported in the headwaters of the Kinder Plateau (Allott et al., 2009; Rothwell et al., 2008; Evans et al., 2006). A recent study (Shuttleworth et al., 2015) found that the ongoing restoration of these headwater systems by Moors for the Future Partnership have reduced sediment fluxes by two orders of magnitude compared to eroding sites. However, Kinder Reservoir sedimentation rate was not measured in this present study. Further research on benthic sediment composition, denitrification rates, and DON characterisation is needed to provide complete ecosystem analysis and conclusive evidence of the prevailing mechanism of $\mathrm{N}$ retention/removal in this acid sensitive fluvial system. 


\section{Conclusion}

The $\mathrm{N}$ mass balance results show a $\sim 21$ to $31 \%(1665-2953 \mathrm{~kg} \mathrm{~N})$ retention of TDN input to the Kinder Reservoir during the study year. With regards to the species of TDN, $\sim 6$ to $13 \%$ of DIN, and 39 to $55 \%$ of DON fluxes were retained or cycled by the reservoir. The long WRT ( $\sim 104$ days), average $\mathrm{pH}$ of 6.5 and high average concentrations of DIN, particularly in spring and early summer in the reservoir suggests that denitrification is potentially a key mechanism of $\mathrm{N}$ retention/removal. This study also demonstrates the importance of DON in the $\mathrm{N}$ cycling and biogeochemistry of upland freshwater systems. Whilst the Kinder Reservoir was a source of DIN in the vegetative season (summer), 58 to $\sim 80 \%(255-730 \mathrm{~kg} \mathrm{~N})$ of DON was retained. This may suggest that DON/DOM is either being photodegraded into DIN in the reservoir or there is rapid utilisation of DON and its photoproducts (e.g. dissolved primary amines) by the microbial community of the reservoir. This has implications for $\mathrm{N}$ limitation in upland freshwater systems where transformation in the availability of bioavailable $\mathrm{N}$ could increase the eutrophic burden of these sensitive fluvial environments.

\section{Acknowledgments}

We are grateful to The University of Manchester for providing a Presidents Doctoral Scholarship Award (to D.A. Edokpa). We thank United Utilities for granting access and permission to conduct this study at the sites. Thanks to Alan Heath and Andrew Stimson for their help with logistics and fieldwork, and Jonathan Yarwood and John Moore for their assistance in the laboratory. We thank the anonymous reviewers for helpful comments which improved the manuscript.

\section{References}

Aber JD, Magill A., McNulty SG, Boone RD, Nadelhoffer KJ, Downs M, Hallett R. 1995. Forest biogeochemistry and primary production altered by nitrogen saturation. Water Air and Soil Pollution 85: 1665-1670. 
Aber JD, Goodale CL, Ollinger SV, Smith M-L, Magill AH, Martin ME, Hallett RA, Stoddard JL. 2003. Is nitrogen deposition altering the nitrogen status of northeastern forests? BioScience 53: 375-389.

Adams R, Costelloe JF, Western AW, George B. 2013. Using uncertainty analysis and groundwater measurements to improve the confidence of river water balance estimates. Journal of Hydrology 503: 209-221.

Aherne J, Dillon PJ, Cosby BJ. 2003. Acidification and recovery of aquatic ecosystems in south central Ontario, Canada: regional application of the MAGIC model. Hydrology and Earth System Sciences 7: 561-573.

Allott TEH, Evans MG, Lindsay JB, Agnew CT, Freer JE, Jones A, Parnell M. 2009. Water tables in Peak District blanket peatlands, Moors for the Future, Report No 17.

Baron JS, Driscoll, CT, Stoddard JL, Richer EE. 2011. Empirical critical loads of atmospheric nitrogen deposition for nutrient enrichment and acidification of sensitive US lakes. BioScience 61: 602-613.

Battin TJ, Luyssaert S, Kaplan LA, Aufdenkampe AK, Richter A, Tranvik LJ. 2009. The boundless carbon cycle. Nature Geoscience 2: 598-600.

Bertilsson S, Tranvik LJ. 2000. Photochemical transformation of dissolved organic matter in lakes. Limnology and Oceanography 45: 753-762.

Beven K. 2006. Searching for the Holy Grail of scientific hydrology: Qt $=H(S, R, D t) A$ as closure. Hydrology and Earth System Sciences 10: 609-618.

Bradley PM, Aelion CM, Vroblesky DA. 1992. Influence of environmental factors on denitrification in sediment contaminated with JP-4 jet fuel. Ground Water 30: 843-848.

Brodrick SJ, Cullen P, Maher W. 1988. Denitrification in a natural wetland receiving secondary treated effluent. Water Research 22: 431-439.

Cape, J.N., Kirika, A., Rowland, A.P., Wilson, D.R., Jickells, T.D. and Cornell, S. (2001) Organic nitrogen in precipitation: Real problem or sampling artefact? TheScientificWorld 1: 230-237.

Chapman LJ, Chapman CA, Crisman TL, Nordlie FG. 1998. Dissolved oxygen and thermal regimes of a Ugandan crater lake. Hydrobiologia 385: 201-211.

Cooper DM, Jenkins A. 2003. Response of acid lakes in the UK to reductions in atmospheric deposition of sulphur. Science of the Total Environment 313: 91-100.

Cooper DM. 2005. Evidence of sulphur and nitrogen deposition signals at the United Kingdom Acid Waters Monitoring Network sites. Environmental Pollution 137: 41-54. 
Crisp DT. 1966. Input and output of minerals for an Area of Pennine Moorland: The importance of precipitation, drainage, peat erosion and animals. Journal of Applied Ecology 3: $327-348$.

Curtis C, Allott T, Hall J, Harriman R, Helliwell R, Hughes M, Kernan M, Reynolds B, Ullyett J. 2000. Critical loads of sulphur and nitrogen for freshwaters in Great Britain and assessment of deposition reduction requirements with the First-order Acidity Balance (FAB) model. Hydrology and Earth System Sciences 4: 125-140.

Curtis CJ, Evans CD, Helliwell RC, Monteith DT. 2005. Nitrate leaching as a confounding factor in chemical recovery from acidification in UK upland waters. Environmental Pollution 137: $73-82$.

Curtis CJ, Heaton THE, Simpson GL, Evans CD, Shilland J, Turner S. 2012. Dominance of biologically produced nitrate in upland waters of Great Britain indicated by stable isotopes. Biogeochemistry 111: 535-554.

Daniels SM, Evans MG, Agnew CT, Allott THE. 2012. Ammonium release from a blanket peatland into headwater stream systems. Environmental Pollution 163: 261-272.

David MB, Wall LG, Royer TV, Tank JL. 2006. Denitrification and the nitrogen budget of a reservoir in an agricultural landscape. Ecological Applications 16: 2177-2190.

Dean WE, Gorham E. 1998. Magnitude and Significance of Carbon Burial in Lakes, Reservoirs, and Peatlands. Geology 26: 535-538.

Dillon PJ, Somers KM, Findeis J, Eimers MC. 2003. Coherent response of lakes in Ontario, Canada to reductions in sulphur deposition: the effects of climate on sulphate concentration. Hydrology and Earth System Sciences 7: 583-595.

Downing JA, Cole JJ, Middelburg JJ, Striegl RG, Duarte CM, Kortelainen P, Prairie YT, Laube, KA. 2008. Sediment organic carbon burial in agriculturally eutrophic impoundments over the last century. Global Biogeochemical Cycles 22: GB1018. DOI:10.1029/2006GB002854

Downing JA, Prairie YT, Cole JJ, Duarte CM, Tranvik LJ, Striegl RG, McDowell WH, Kortelainen P, Caraco NF, Melack JM, Middelburg JJ. 2006. The global abundance and size distribution of lakes, ponds, and impoundments. Limnology and Oceanography 51: 23882397.

Duan N. 1983. Smearing estimate - a nonparametric retransformation method. Journal of the American Statistical Association 78: 605-610.

Durand P, Breuer L, Johnes P J, Billen G, Butturini A, Pinay G, van Grinsven H, Garnier J, Rivett M, Reay DS, Curtis C, Siemens J, Maberly S, Kaste O, Humborg C, Loeb R, de Klein J, Hejzlar J, Skoulikidis N, Kortelainen P, Lepisto A, Wright R. 2011. Nitrogen processes in 
aquatic ecosystems. In The European Nitrogen Assessment, Sutton MA, Howard CM, Erisman JW, Billen G, Bleeker A, Grennfelt P, van Grinsven H, Grizzetti B (eds.). Cambridge University Press: Cambridge; 126-146.

Edokpa DA, Martin MG and Rothwell JJ. 2015. High fluvial export of dissolved organic nitrogen from a peatland catchment with elevated inorganic nitrogen deposition. Science of the Total Environment 532: 711-722.

Elser JJ, Andersen T, Baron JS, Bergstrom A-K, Jansson M, Kyle M, Nydick KR, Steger L, Hessen DO. 2009. Shifts in Lake N:P Stoichiometry and Nutrient Limitation Driven by Atmospheric Nitrogen Deposition. Science 326: 835-837.

Elser JJ, Bracken MES, Cleland EE, Gruner DS, Harpole WS, Hillebrand H, Ngai JT, Seabloom EW, Shurin JB, Smith JE. 2007. Global analysis of nitrogen and phosphorus limitation of primary producers in freshwater, marine and terrestrial ecosystems. Ecology Letters 10: 1135-1142.

Ensign SH, Doyle MW. 2006. Nutrient spiralling in streams and river networks, Journal of Geophysical Research 111: G04009. DOI: 10.1029/2005JG000114.

Evans CD, Jenkins A, Wright RF. 2000. Surface water acidification in the south Pennines I. current status and spatial variability. Environmental Pollution 109: 11-20.

Evans M, Warburton J, Yang J. 2006. Eroding blanket peat catchments: global and local implications of upland organic sediment budgets. Geomorphology 79: 45-57.

Fazzolari E, Nicolardot B, Germon JC. 1998. Simultaneous effects of increasing levels of glucose and oxygen partial pressures on denitrification and dissimilatory reduction to ammonium in repacked soil cores. European Journal of Soil Biology 34: 47-52.

Fuhrman, J. (1990) Dissolved free amino acid cycling in an estuarine outflow plume. Marine Ecology Progress Series 66: 197-203.

Futter MN, Valinia S, Lofgren S, Kohler SJ, Folster J. 2014. Long-term trends in water chemistry of acid-sensitive Swedish lakes show slow recovery from historic acidification. AMBIO 43: 77-90.

Garnier, J, Leporcq B, Sanchez N, Philippon X. 1999. Biogeochemical mass-balances (C, N, $\mathrm{P}, \mathrm{Si}$ ) in three large reservoirs of the Seine Basin (France). Biogeochemistry, 47: 119-146.

Goodale CL, Aber JD, McDowell WH. 2000. The long-term effects of disturbance on organic and inorganic nitrogen export in the White Mountains, New Hampshire. Ecosystems 3: 43350 .

Gruca-Rokosz R, Tomaszek JA, Koszelnik P. 2009. Denitrification in the sediment of a eutrophic reservoir measured with the isotope pairing technique. International Journal of Oceanography and Hydrobiology 38: 75-81. 
Haggard BE, Soerens TS, Green WR, Richards RP. 2003. Using regression methods to estimate stream phosphorus loads at the Illinois River, Arkansas. Applied Engineering in Agriculture 19: 187-194.

Hedges JI, Keil RG. 1999. Organic geochemical perspectives on estuarine processes: sorption reaction and consequences. Marine Chemistry 65: 55-65.

Hedges JI, Keil RG. 1995. Sedimentary organic matter preservation: an assessment and speculative synthesis. Marine Chemistry 49: 81-115.

Helliwell RC, Davies JJL, Evans CD, Jenkins A, Coull MC, Reynolds B, Norris D, Ferrier RC. 2007. Spatial and seasonal variation in nitrogen leaching and acidity across four acidimpacted regions of the UK. Water, Air and Soil Pollution 185: 3-19.

Henrichs SM, Sugai SF. 1993. Adsorption of amino acids and glucose by sediments of Resurrection Bay, Alaska, USA: Functional group effects. Geochimica et Cosmochimica Acta 57: 823-835.

Hope D, Billett MF, Cresser MS. 1997. Exports of organic carbon in two river systems in NE Scotland. Journal of Hydrology 193: 61-82.

Ittekkot V, Zhang S. 1989. Pattern of particulate nitrogen transport in World Rivers. Global Biogeochemical Cycles 3: 383-391.

Jansson M, Andersson R, Berggren H, Leonardson L. 1994. Wetlands and Lakes as nitrogen traps. Ambio 23: 320-325.

Jorgensen NOG, Tranvik L, Edling H, Granéli W, Lindell M. 1998. Effects of sunlight on occurrence and bacterial turnover of specific carbon and nitrogen compounds in lake water. FEMS Microbiology Ecology 25: 217-227.

Katterer T. 2011. Nitrogen Budgets. In Encyclopedia of Life Sciences. John Wiley and Sons Ltd: Chichester. DOI: 10.1002/9780470015902.a0003189.pub2

Kaushal SS, Lewis WM Jr. 2005. Fate and transport of organic nitrogen in minimally disturbed montane streams of Colorado USA. Biogeochemistry 74: 303-321.

Kelly VJ. 2001. Influence of reservoirs on solute transport: a regional-scale approach. Hydrological Processes 15: 1227-1249.

Klemedtsson L, Svensson BH, Lindberg T, Rosswall T. 1977. The use of acetylene inhibition of nitrous oxide reductase in quantifying denitrification in soils. Swedish Journal of Agricultural Research 7: 179-185.

Knowles R. 1982. Denitrification. Microbial Reviews 46: 43-70. 
Kohler S, Buffam I, Jonsson A, Bishop K. 2002. Photochemical and microbial processing of stream and soil water dissolved organic matter in a boreal forested catchment in northern Sweden. Aquatic Sciences 64: 269-281.

Kunz MJ, Anselmetti FS, Wuest A, Wehrli B, Vollenweider A, Thuring S, Senn DB. 2011. Sediment accumulation and carbon, nitrogen, and phosphorus deposition in the large tropical reservoir Lake Kariba (Zambia/Zimbabwe). Journal of Geophysical Research 116: G03003. DOI: $10.1029 / 2010 J G 001538$

Lepori F, Keck F. 2012. Effects of atmospheric nitrogen deposition on remote freshwater ecosystems. Ambio 41: 235-246.

Lin L, Webster JR, Hwang T, Band LE. 2015. Effects of lateral nitrate flux and instream processes on dissolved inorganic nitrogen export in a forested catchment: A model sensitivity analysis. Water Resources Research 51: 2680-2695.

Linacre ET. 1977. A simple formula for estimating evaporation rates in various climates using temperature data alone. Agricultural Meteorology 18: 409-424.

Moran MA, Zepp RG. 1997. Role of photoreactions in the formation of biologically labile compounds from dissolved organic matter. Limnology and Oceanography 42: 1307-1316.

Noges P, Jarvet A, Tuvikene L, Noges T. 1998. The budget of nitrogen and phosphorous in shallow eutrophic Lake Vortsjarv (Estonia). Hydrobiologia 363: 219-227.

Roley SS, Griffiths JR, Levi PS, Patrick CJ, Sadro S, Zarnetske JP. 2014. Taking the pulse of the ecosystem: progress in quantifying aquatic ecosystem health. Eco-DAS X Chapter 7: 101118. DOI: $10.4319 /$ ecodas.2014.978-0-9845591-4-5.101

Rothwell JJ, Evans MG, Daniels SM, Allott TEH. 2008. Peat soils as a source of lead contamination to upland fluvial systems. Environmental Pollution 153: 582-589.

Rutting T, Boeckx P, Muller C, Klemedtsson L. 2011. Assessment of the importance of dissimilatory nitrate reduction to ammonium for terrestrial nitrogen cycle. Biogeosciences $\mathbf{8}$ : 1779-1791.

Saunders DL, Kalff J. 2001. Nitrogen retention in wetlands, lakes and rivers. Hydrobiologia 443: $205-212$.

Scott JT, McCarthy MJ, Gardner WS, Doyle RD. 2008. Denitrification, dissimilatory nitrate reduction to ammonium, and nitrogen fixation along a nitrate concentration gradient in a created freshwater wetland. Biogeochemistry 87: 99-111.

Seitzinger SP. 1988. Denitrification in freshwater and coastal marine ecosystems: Ecological and geochemical significance. Limnology and Oceanography 33: 702-724. 
Seitzinger SP, Sanders RW. 1997. Contribution of dissolved organic nitrogen from rivers to estuarine eutrophication, Marine Ecology Progress Series, 159, 1-12.

Shotbolt LA, Thomas AD, Dougill AJ, Hutchinson, SM. 2000. Reconstructing the history of heavy metal pollution in the southern Pennines from the sedimentary record of reservoirs: methods and preliminary results. The North West Geography 3: 3-20.

Shotbolt LA, Thomas AD, Hutchinson SM. 2005. The use of reservoir sediments as environmental archives of catchment inputs and atmospheric pollution. Progress in Physical Geography 29: 337-361.

Shuttleworth EL, Evans MG, Hutchinson SM, Rothwell JJ. 2015. Peatland restoration: controls on sediment production and reductions in carbon and pollutant export. Earth Surface Processes and Landforms 40: 459-472.

Skjelkvale BL, Evans C, Larssen T, Hindar A, Raddum GG. 2003. Recovery from acidification in European surface waters: a view to the future. Ambio 32: 170-175.

Steffen W, Broadgate W, Deutsch L., Gaffney O, Ludwig C. 2015. The trajectory of the Anthropocene: The Great Acceleration. The Anthropocene Review 1-8. DOI: $10.1177 / 2053019614564785$.

Stoddard JL. 1994. Long-term changes in watershed retention of nitrogen: its causes and aquatic consequences. In Environmental Chemistry of Lakes and Reservoirs Advances in Chemistry Series 237, L. Baker (ed.). American Chemical Society:

Washington DC; 223-284.

Stoddard JL, Jeffries DS, Lukewille A, Clair TA, Dillon PJ, Driscoll CT, Forsius M, Johannessen M, Kahl JS, Kellogg JH, Kemp A, Mannio J, Monteith DT, Murdoch PS, Patrick S, Rebsdorf A, Skjelkvale BL, Stainton MP, Traaen, T, van Dam H, Webster KE, Wieting J, Wilander A. 1999. Regional trends in aquatic recovery from acidification in North America and Europe. Nature 401: 575-578.

Sun P, Zhuge Y, Zhang J, Cai Z. 2012. Soil pH was the main controlling factor of the denitrification rates and $\mathrm{N}_{2} / \mathrm{N}_{2} \mathrm{O}$ emission ratios in forest and grassland soils along the Northeast China Transect (NECT). Soil Science and Plant Nutrition 58: 517-525.

Tallis JH. 1997. Peat erosion in the Pennines: the Badlands of Britain. Biologist 44: 277-279.

Tang H, Xie P. 2000. Budgets and dynamics of nitrogen and phosphorous in a shallow, hypereutrophic Lake in China. Journal of Freshwater Ecology 15: 505-514.

Thornton KW, Kimmel BL, Payne FE (eds.). 1990. Reservoir Limnology: Ecological Perspective. John Wiley \& Sons: New York. 
Toetz DW. 1973. Nitrogen Budgets of Great Plains Impoundments. In Man-made lakes: their problems and environmental effects, Achermann WC, White GF, Worthington EB (eds.). American Geophysical Union: Washington, D.C.; 567-571.

Tranvik LJ, Downing JA, Cotner JB, Loiselle SA, Striegl RG, Ballatore TJ, Dillon P, Finlay K, Fortino K, Knoll LB, Kortelainen PL, Kutser T, Larsen S, Laurion I, Leech DM, McCallister SL, McKnight DM, Melack JM, Overholt E, Porter JA, Prairie Y, Renwick WH, Roland F, Sherman BS, Schindler DW, Sobek S, Tremblay A, Vanni MJ, Verschoor AM, von Wachenfeldt E, Weyhenmeyera GA. 2009. Lakes and reservoirs as regulators of carbon cycling and climate. Limnology and Oceanography 54: 2298-2314.

United Utilities. 2011. Report on adaptation under the Climate Change Act 2000. Accessed on $01 / 04 / 2015$ at $16: 57$ from http://corporate.unitedutilities.com/documents/UUW_Climate_change_adaptation_report_FI NAL.pdf

Vahatalo AV, Zepp RG. 2005. Photochemical mineralization of dissolved organic nitrogen to ammonium in the Baltic Sea. Environmental Science and Technology 39: 6985-6992.

Vogt E, Braban CF, Dragosits U, Theobald MR, Billett MF, Dore AJ, Tang YS, van Dijk1 N, Rees RM, McDonald C, Murray S, Skiba1 UM, Sutton MA. 2013. Estimation of nitrogen budgets for contrasting catchments at the landscape scale. Biogeosciences 10: 119-133.

Walling DE, Webb BW. 1985. Estimating the discharge of contaminants to coastal waters by rivers: some cautionary comments. Marine Pollution Bulletin 16: 488-492.

Wang JH, Baltzis BC, Lewandowski GA. 1995. Fundamental denitrification kinetic studies with psuedomonas denitrificans. Biotechnology and Bioengineering 47: 26-41.

Weier KL, Gilliam JW. 1986. Effect of acidity on denitrification and nitrous oxide evolution from Atlantic Coastal Plain soils. Soil Science Society of America Journal 50: 1202-1205.

Winter JG, Dillon PJ, Futter MN, Nicholls KH, Scheider WA, Scott LD. 2002. Total phosphorus budgets and nitrogen loads: Lake Simcoe, Ontario (1990 to 1998). Journal of Great Lakes Research 28: 301-314.

Wolfe AP, Baron JS, Cornett RJ. 2001. Anthropogenic nitrogen deposition induces rapid ecological changes in alpine lakes of the Colorado Front Range (USA). Journal of Paleolimnology 25: 1-7.

Worrall F, Harriman R, Evans CD, Watts C, Adamson J, Neal C, Tipping E, Burt TP, Grieve I, Montieth D, Naden PS, Nisbet T, Reynolds B, Stevens P. 2004. Trends in dissolved organic carbon in UK rivers and lakes. Biogeochemistry 70: 369- 402. 
Yesmin L, Gammack SM, Sanger LJ, Cresser MS. 1995. Impact of atmospheric N deposition on inorganic and organic N outputs in water draining from peat. Science of the Total Environment 166: 201-209.

Yin S, Shen Q, Tang Y, Cheng L. 1998. Reduction of nitrate to ammonium in selected paddy soils in China. Pedosphere 8: 221-228. 